\title{
Impact of advertising on consumer purchase decision among university students
}

Lau, Hui Hong John

University Malaysia Sarawak (UNIMAS), Malaysia (johnlau7861@gmail.com)

Wah, Nur Constance $\triangle$

University Malaysia Sarawak (UNIMAS), Malaysia (wnconstance@unimas.my)

Khalique, Muhammad

Mirpur University of Science and Technology (MUST), Pakistan (drmkhalique@gmail.com)

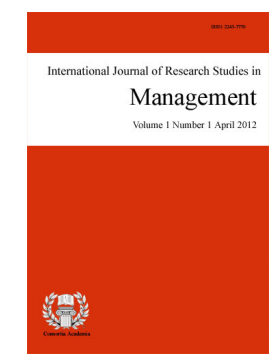

ISSN: $2243-7770$ Online ISSN: 2243-7789

OPEN ACCESS

\section{Abstract}

Advertising is an integral part of the business enterprises to attract consumers and it often uses in the society. In society, advertising has many shapes such as billboard, poster, television, telephone, social media, print media and radio. This study aims to determine the impact of advertising on consumer purchase decision among the undergraduate students in Sarawak public university. To achieve the objective of the study, AIDA Model was employed. Structured survey forms were used to gather the data from the targeted respondents. Purposive sampling technique was used to select the students and 383 individuals participated in the study. Four research hypotheses were established, based on strong theoretical foundation. Multiple regression analysis was used to test the proposed research hypotheses and findings express four research hypotheses were supported. The results of this study imply that AIDA Model is useful for successful advertising.

Keywords: AIDA model, advertising, consumer purchase decision, university, students 


\section{Impact of advertising on consumer purchase decision among university students}

\section{Introduction}

In contemporary business, world advertising is considered as one of the most vital components of the business success and sustainability. Harahap and Amanah (2020) has conducted their study in SMEs and to determinants the consumer purchase decision and they found that the competition of the SME company to win each other's in the market of fulfill customer need and desired by using advertising is necessary nowadays. However, advertising need to spend a lot of time and money and it will go in vain if consumers did not have any positive influence to the advertising.

Not only this, according to Chukwu et al. (2019) in their study "the impact of advertising on consumer buying behavior states that most consumer and organization pay lukewarm attitude in advertising to promote their goods and services. They don't want to spend more extra budget in advertising and they feel it cannot influence consumer buying behavior. So, they will not consider about using advertising to promote their goods and services. It is also similarly to the research of Yelbert (2010), the research on advertising on students' purchase behavior (Yelbert, 2010). In that research, Yelbert, (2010) describe the majority of viewers and consumers consider advertisement is probably fake and they try to persuade viewers who look at the advertisement to purchase the products. Apart from that, they do believe great products do not inevitably use an advertisement to promote it because the great product and service will sell automatically without using any platform.

Nowadays, many products in the advertisement just have good-looking instead of having a good quality that is described in the advertising. According to Klein (2000), she says that a lot of companies instead of generating good and quality products, the more likely to produce an image of things. It is undeniable to say that advertising is still the best way to promote products. Advertising creates attention to the consumer of the products and aims to make brand recall from them (Ingavale, 2013). Advertising bridges the gap between its target market and companies. Advertising nowadays has successfully created a platform that provides many opportunities to a company to introduce their new product in the current market to remind or raise awareness of consumers about the existing products. Regarding to Bludova et al. (2019), the use of advertising is allowing marketers to reach its target audience and influence their purchase decision. According to (Kamins et al., 1989), advertisers often use advertisement as a pursue strategies to attract consumers' attention to their products to raise the difference of the product for competing products and influence purchase from the consumer.

Based on Perreault and McCarthy (1997), the study saying that advertisement is defined as a paid tool for a company to promote the product to consumers from different platforms. The advertising is a tool to help an organization to promote and raise awareness of a product to the consumer by an identified sponsor. All these definitions clearly expressing that every product, services, ideas being promote into advertisement has an identifiable sponsor at the back. According to Belch and Belch (2003) in society nowadays, advertising has become a vital method for both marketers and consumers. In short, advertising tries to create an optimistic image of brand and mind in order to interest consumer to it and become a loyal customer to the product.

Advertising takes many forms nowadays in the market to influence the consumer. Different advertising will use different platforms to make full use of the power in advertising like a radio channel, television, internet and poster, banners, billboards to expose the information to consumers (Robbs, 2009). Therefore, this study addresses whether the impact of advertising have the relationship between consumer purchase decision among the UNIMAS students based on AIDA model. 


\section{Literature Review and hypotheses development}

\subsection{Effectiveness of advertising on consumer purchase decision}

According to Sah (2020), advertising is not only a tool to consumer make their purchase decision whereas it is an important tool to connect the relationship with customers and the organizations. Through advertising, it can create more opportunity for an organization to earn the profit. It continues states that a lot of company pay less attention on advertising through radio, magazine and newspaper but spend more in internet advertising. This is because they all believe now is a good time to promote their goods and services through internet such as social media. Consumer purchase decision will be easily influence by the advertising on internet. In short of the research, Sah concluded that it is undeniable to say that advertising is still one of the most important and effectiveness way to attracted more consumer and influence their purchase decision.

Hassan (2016) conducted a research on the effects of television advertisements on consumer buying behavior and the focus of the study was between the gender of rural and urban areas. He found influence on the purchase behavior of television advertising on the residential background of the consumers. In this study, Hassan also compares both males and females of the effects on television advertising. The sample data, Hassan collects it in the Gujranwala city and its nearby villages. The result of this study indicated that rural consumers like television advertising compare to urban consumers. Next, Hassan also stated that based on the data his collect, basically, urban residents do not purchase any item or services in the television advertisement unless they necessary need it. Hassan in his finding concludes that both male and female are awareness to television advertising while the effect of advertising in television is more effective to rural residents compared to urban residents. Both of the residents or consumers also look good to the advertisements in the future to influence more on consumer attitude and behavior.

Fatima and Lodhi, (2015) states that advertising had used from the past until now generation, but it still works and had a great impact on creating awareness and desire among the customers. They found advertising is a very vital and useful tool to build the attention and desire to the target consumers. The advertising of a product will have a significant awareness to consumers. The consumers will notice and follow the trend of fashion through advertisement. In the end, after exposure to the advertising, consumers will have the interest and the desire to the product. Hence, it will bring a positive image and result to the product. A positive relationship between awareness and desire will build a good motivation to motivate them to purchase the products. (Fatima $\&$ Lodhi, 2015).

Kabarwala (2019) argued that today advertising act a one way that have favorable impact to the consumer buying behavior. Advertising bring many advantages more than disadvantages to marketers. It can use in many forms to gain attention of consumers and influence their buying behavior. According to Rai (2013), advertising plays a significant role to influence consumer's attitude and behavior of the buying decision in this modern and information era. He further explains to the words and says that the influence of attitude and behavior of consumer buying decision happen in the style of advertisements. He evaluates that when a person exposed to advertising, it will increase the awareness of the products. Hence, advertising will have a great impact on the purchasing decision of the consumer. Rai stated that the success of the advertising is equal to the efforts that put into the advertisement. Good advertising will make a positive effect, and persuasive results to serve the need of expectation for the consumers. This study also supported that advertising had the power of motivates consumers purchase durable goods. The consumers induced and influence on the advertisements of their purchase attitude and behavior.

\subsection{Awareness of Advertising}

Hypothesis 1: Awareness of advertising has a positive and significant effect on the consumer purchase decision. 
Elnaga and Abunayyan (2016) argued that the awareness is the first step of AIDA model, it is the step at the beginning to consumer to build attention to the products that are advertised. In the stage, something is used to attract the reader's or the viewer's attention. Advertisers introduce their products and services. It can be in any type of advertising with the art or the word to write information about the usage of the products. In this stage advertising is to get the awareness of the consumer of the products or services. Regarding to Martins (2019), brand awareness among advertising will have a huge impact to consumer purchase intention. It shows that awareness created by advertising through smart-phone allows marketers to know better in the market and created advertising that will contributed to consumer purchase intention. Ashcroft and Hoey (2001) argued that the awareness is a communication tool and the cognitive period to attract consumer attention. The word, style, color, size frequently used to attract consumers' attention to the advertisement and the product and service. According to (Mullner et al., 2005), the purpose of advertisers to make advertising is to gain attention or awareness to their products to its target market in the purpose to gain benefit on it to the company.

\subsection{Interest of Advertising}

Hypothesis 2: Interest of advertising has a positive and significant effect on the consumer purchase decision.

Interest is the second step of Aida model. It has aimed to create an interest with an aggressive sales force (Elnaga \& Abunayyan, 2016). Advertisement of a product and services create with the higher interest among the target market or viewers. This is because the interest among target market and viewers is the priority of advertisement (Rowley, 1998). If a buyer becomes loyalty to a product and keeps, purchasing the same product shows consumers' interest in the product (Ghirvu, 2013). According to (Rehman et al., 2015), sometimes customers think that they are being treats personally and they will show the greater interest to their offer in the advertising. This is one of the opportunities to make choice for creating greater business interest.

\subsection{Desire of Advertising}

Hypothesis 3: Desire of advertising has a positive and significant effect on the consumer purchase decision.

At the third step of AIDA mode, it is a step to discuss with the aspiration of the target market to purchase products or services. According to Palcu et al. (2019), desire is actually same as the actual consumption. Consumers will have a desire to having the product and services that advertised. Based on the advertising point of view, a desire is the most important step to a consumer before purchase any product and services (Elnaga \& Abunayyan, 2016). Desire can define as to be a high level of having a product (Rehman et al., 2015). Advertisers are trying to provide the best view of the product in the advertisement to consumers (Rowley, 1998). According to Khan et al. (2012, desire of advertising will give impact to consumer purchase decision.

\subsection{Action of Advertising}

Hypothesis 4: Desire of advertising has a positive and significant effect on the consumer purchase decision.

The last stage of AIDA model, the customer is prepared to purchase and pay to the products or services to fulfill their desire for a particular product or service (Rehman et al., 2015). Zeng et al. (2019) argued that the action would strongly relate to consumer purchase intention. This is because they might already target what item in advertising they might need to purchase. Not only this, several intensive offers to the products in the advertisement will increase the rate of a customer to purchase the product (Rowley, 1998). The consumer will enjoy the complete process of an offer done through start from the beginning, which is awareness, interest, desire and action (Elnaga \& Abunayyan, 2016).

4 Consortia Academia Publishing (A Partner of Tourism Educators and Movers of the Philippines) 


\section{Theoretical foundation}

\subsection{AIDA MODEL}

AIDA is frequently used for advertising purpose from long time (Fortenberry \& McGoldrick, 2020). Elmo Lewis established it, and it applies by many marketers to explain the different phase of the consumer in an advertisement. According to Colley (1984), AIDA model is a model that describes the process of the consumer when they exposed to the advertising in any media. In order to adhere a successful advertising communication, potential buyers or target market become the target to the marketer for advertising messages (Rossitor \& Percy, 1985). Action can become a part to desire target behavior to the consumers. Aida model also a model that describes an individual going through the process in order to become a potential consumer. The stages of the model can be identified by four steps, which are awareness, interest, desire and action (Glowa, 2002).

This model can easily explain the awareness can cause an increase of the attention and attract customer to purchase the product. Next, it will start to gain the interest of the consumer to the product and service and it is possibly influenced to consumer's desire for the product. Advertiser believes that if the consumer already reaches the step of desire, he or she is likely to take the last step, which is action to purchase the product (Lavidge \& Steiner, 1961). A different marketer will use different information in order to maximize the function of the advertising to make consumers aware by the prepare information in the advertising. Some of the information in the advertising is through modern style, the color, the size, persuasive information and the goof looking image to convince the consumer or target market about the benefit and advantages to purchase the product or services, and how that product to easy our life after the consumer purchase it. Therefore, the thing that majority advertisers do is actually a necessary for the information to do the best to increase the interest of the consumer to know the benefit of the goods that are being promoted by the advertising (Hansen, 1972).

The desire is to create after they exposed to the advertising that convinces them of the information. In this stage, the consumer already knows what they need after exposed by a lot of information. Advertisers defined their offer and the value of the product. Lastly, people will take action on it (Jones, 1986). Action in the last stage in Aida model is a result of the process. Before a consumer purchase and pay for a product. He must be aware of the product from any form of advertising that gives them the messages. After he is interested in the product, he will create a strong desire to the product. This is because, on that, stage the consumer already knows what is the need of him to purchase a product. Hence, the fourth or the last stage will come as a result of the movement of AIDA model through the three stages of awareness, interest and desire (Bovee et al., 1995). Model is represented in given below Figure 1.

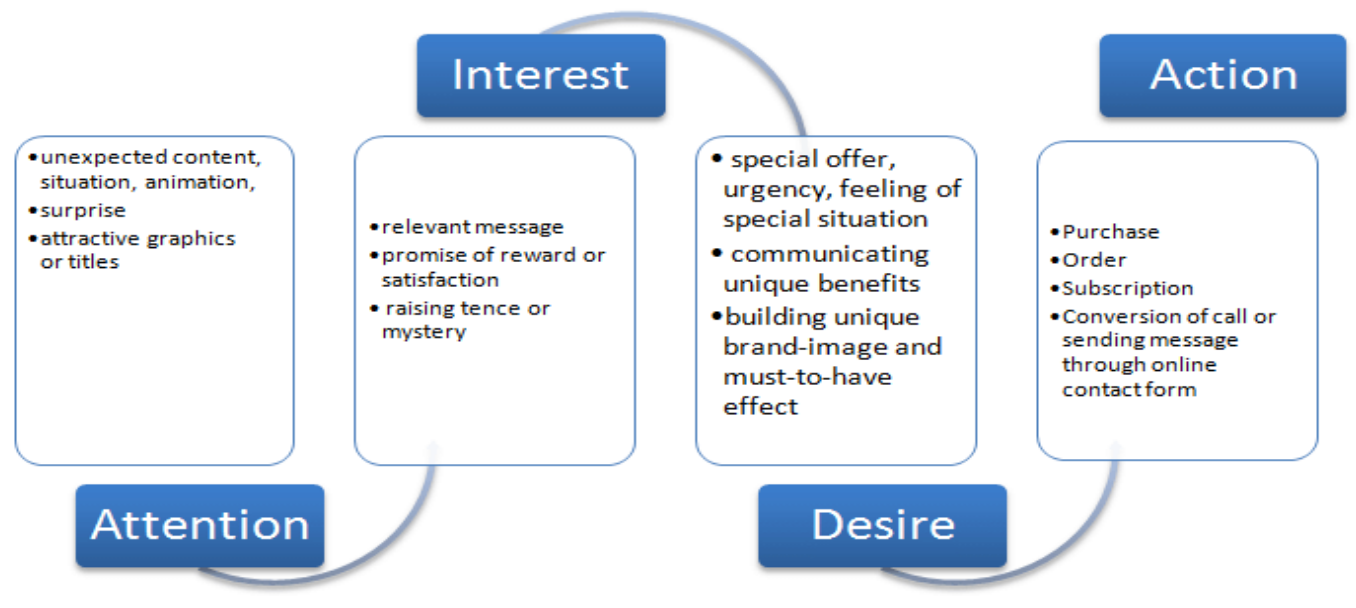

Figure 1: AIDA model 


\subsection{Research Methodology}

This study is cross sectional and quantitative in nature. Structured questionnaire surveys were operationalized to gather the primary data from the targeted respondents. The data were gathered through google form. In this study, the target population who has a common set of characteristics would be UNIMAS students. The reason to set target population is that they are the suitable population in this research since their all exposed to advertisement daily and influence by the advertisement in term of employed factors. Therefore, UNIMAS students are most suitable target population in this research. The sample represents the population. In order to minimize the misunderstanding and bias within the sample selected, the target sampling methods is important to the research. In this research, students were selected in UNIMAS from different faculties to represent the population. Probability of sampling method was selected for this research. The sample frame in this research was the students enrolled in the faculties of UNIMAS. To select an appropriate sample size for this research, the confidence level was $95 \%$, the standard deviation 0.5 and a margin of error of $5 \%$. The number of respondents allocated for the study is 385 respondents from UNIMAS students. Evidence number of respondents required is shown below. This study has successfully received data from 383 out of 500 UNIMAS students.

$$
\begin{aligned}
\text { Necessary sample size }= & \frac{\left[(1.96)^{2}(0.5)(0.5)\right]}{(0.05)(2)} \\
& =384.16 \\
& =385 \text { respondents }
\end{aligned}
$$

\section{Results}

Before data analysis the data set was screened, cleaned and examined for the normalcy. The results expressed that the gathered data is ready for further analysis. Reliability of measurement scale was examined through Cronbach's Alpha test, which is the preferred approach to test the reliability of the scale (Field, 2005). The approved range of the Cronbach Alpha is more than 0.7 and above. Table 1 reported that all employed constructs met the suggested thresholds. Results expressed that the Cronbach's Alpha of awareness of advertising is 0.810 , interest of advertising is 0.821 , desire of advertising is 0.834 , action of advertising is 0.826 and consumer purchase decision is 0.793 . From the result of the analysis, the Cronbach's Alpha of independent variables (Awareness of advertising, interest of advertising, desire of advertising, action of advertising) and dependent variable (Consumer purchase decision) are all acceptable as the results are more than 0.7 and above. Findings showed that the reliability of the measurement scale is established.

Table 1

Reliability test of the employed constructs

\begin{tabular}{lcc}
\hline \multicolumn{1}{c}{ Constructs } & Items & Cronbach Alpha \\
\hline Awareness of advertising & 4 & 0.810 \\
Interest of advertising & 4 & 0.821 \\
Desire of advertising & 4 & 0.834 \\
Action of advertising & 4 & 0.826 \\
Consumer Purchase Decision & 4 & 0.793 \\
\hline
\end{tabular}

\subsection{Hypotheses testing}

Khalique et al. argued that multiple regression is a robust technique to examine the prediction of predictors to the predicted. Multiple regression is widely used to test the research hypotheses. Therefore, in this study, multiple regression analysis approach was used for a better and clearer view of the independent variables namely, awareness of advertising (AOA), interest of advertising (IOA), desire of advertising (DOA), action of advertising

6 Consortia Academia Publishing (A Partner of Tourism Educators and Movers of the Philippines) 
Impact of advertising on consumer purchase decision among university students

(AA) on dependent variable which is consumer purchase decision (CPD). In multiple regression R-square is used to examine the variance explained by the independent variables to dependent variable. Result showed that $\mathrm{R}$ square value is 0.739 , which indicates $73.9 \%$ variance in consumer purchase decision among the students was explained by the four independents variables. Overall model appeared as significant with F-value $=8.950$ with significance values $p>0.01$. Results of four independent variables were represented in Table 2 .

Table 2

Results of Multiple Regression Analysis

\begin{tabular}{|c|c|c|c|c|c|}
\hline \multirow[t]{2}{*}{ Model } & \multicolumn{2}{|c|}{ Unstandardized Coefficients } & \multirow{2}{*}{$\begin{array}{c}\text { Standardized } \\
\text { Coefficients } \\
\text { Beta }(\beta)\end{array}$} & \multirow[t]{2}{*}{$t$} & \multirow[t]{2}{*}{ Sig. } \\
\hline & $\mathrm{B}(b)$ & Std. Error & & & \\
\hline Awareness of advertising & .219 & .056 & & 3.879 & .000 \\
\hline Interest of advertising & .617 & .134 & .629 & 4.616 & .000 \\
\hline Desire of advertising & .211 & .109 & .189 & .175 & .045 \\
\hline \multirow[t]{2}{*}{ Action of advertising } & .169 & .069 & .174 & 2.432 & .015 \\
\hline & .157 & .088 & .159 & 1.795 & .033 \\
\hline
\end{tabular}

Note: Dependent variable CPD.

Table 2 expressed that the awareness of advertising has been accepted on the basis of strong relationship with the consumer purchase decision, with the result of positive beta value of 0.629 (Sig. $=0.000)$ which achieve a significant level. The reason behind of awareness of advertising have strong relationship with consumer purchase decision and has been accepted, aA most of the respondents of this study are younger generation which is UNIMAS undergraduates and postgraduates. Thus, it can be explaining that respondents at this stage are familiar with using latest technology such as internet. So, they will expose to advertisement in any kind of platform such as Facebook, Instagram, Youtube etc. The exposed to the advertising make them aware or giving attention to the advertising and it will cause the impact to their purchase decision. This is mirror of the previous research done by Awan et al. (2015), which proclaimed that awareness has a positively affecting consumer purchase decision among consumer in Pakistan. He continues stated that generally use awareness in advertising in promoting product will create huge impact to consumer purchase decision. Furaiji (2016) also indicated that advertising attractiveness had a positive awareness towards consumer purchase decision of women and men. Noursina and Ghaffari (2015) found that awareness and attention from advertising have strong relationship with consumer purchase decision. Based on findings it concluded that awareness of advertising has effect on consumer purchase decision among UNIMAS students.

Therefore, hypotheses $H 1$ awareness of advertising has a positive and significant effect on consumer purchase decision was supported.

Interest of advertising is also one of the accepted variables in this study. Based on the findings, it has a positive relationship with consumer purchase decision as the beta value positive 0.189 with a significant value of 0.045. In this study, the researcher also founded that the reason that interest of advertising effected consumer purchase decision is due to nowadays a lot of marketers used brand ambassadors to promote the advertisement. The interesting of the advertising will effect on consumer purchase decision. According to previous research done by Rameez (2020), Fatima, and Lodhi (2015) interest of advertising is also a factor that affects consumer purchase decision. These studies stated that the more attractive information in advertising has increase the interest to consumer and affected in their purchase decision. Researchers concluded that interest of advertising is the most important factor that effects on consumer purchase decision among UNIMAS students.

Therefore, hypotheses $\mathrm{H} 2$ interest of advertising has a positive and significant effect on consumer purchase decision.

Desire of advertising have relationship with consumer purchase decision, beta value was positive 0.174 with significant value $p=0.015$ which fulfil the threshold of significant level. The reason behind desire of advertising have relationship with consumer purchase decision and has been accepted, is because the younger generation 
tend to have desire of the products and they think they need the products before making any purchase decision. Therefore, it means that desire of advertising is directly effect on the consumer purchase decision among UNIMAS students. This study supported by previous studies such as Harahap and Amanah (2020); Cunningham (1968), Lautianinen (2015) and Rai (2013) these studies supported that desire of advertising will relate to consumer purchase decision.

Based on empirical evidence H3 desire of advertising has a positive and significant effect on consumer purchase decision.

Table 2 reported that the action of advertising appeared as significant contributor with beta value 0.159 at $p$ $=0.033$. It has a positive relationship with action of advertising and the consumer purchase decision among UNIMAS students. This study showed similar results with previous studies done by Barry and Howard (1990); Zeng et al. (2019) and Niazi et al. (2012), which indicated that advertising have significant impact on consumer purchase decision. This study concluded that action of advertising is one of the most important factors that effects on consumer purchase decision among UNIMAS students.

Therefore, hypotheses $\mathrm{H} 4$ desire of advertising has a positive and significant effect on consumer purchase decision.

\section{Discussion and conclusion}

The objective of this study was to examine the impact of advertising on consumer purchase decision among the university students in Sarawak Malaysia. Presently, advertising is everywhere, it found in any platforms such as internet, television, newspaper, radio and billboard. If the advertising does not have any effect to consumer, invest in time and money will go waste (Ingavale, 2013). Based on this research, according to AIDA model, it is stated that advertising still have significant effect on consumer purchase decision. In short, it proves that every marketer spend in advertising will not be wasted. However, as found in this research, revealing that awareness of advertising is the most impact variable among the other independent variables in effecting consumer purchase decision among UNIMAS students. This variable showing that most of the respondents were attentive to the advertising will definitely effect their purchase decision.

Therefore, enterprises can more focus on the awareness of advertising to public to promote and gain consumer attention on the product, to compete with others competitors in the marketplace. Indeed, the result of this research on others independent variables are also positively and significantly effect on consumer purchase decision. This study expressed that the others independent variables namely interest of advertising, desire of advertising and action of advertising are very important for business organizations. Marketer should focus all variables in market, this is because all of the independent variables are positive and significant effected to consumer purchase decision.

Limitations and recommendations - Like others studies this research has some limitations. This study was cross-sectional in nature with limited sample size. Therefore, the generalizability of the results could be limited. This study focus UNIMAS students only, thus, the future researchers can target more groups from different universities in Malaysia from private and public sector to get more holistic and valid outcomes. This study recommends to the potential researchers could strengthen the demographic part so they can better understand the behavior and background of the respondents. Furthermore, the future researchers may use consumer perception of advertising and consumer expenses with advertised products as the independent variables to investigate consumer purchase decision among consumer in Malaysia.

Acknowledgement - The authors would like to thank UNIMAS for the Special MyRA Assessment Funding with Project ID: F01/SpMYRA/1691/201

8 Consortia Academia Publishing (A Partner of Tourism Educators and Movers of the Philippines) 


\section{Reference}

Ashcroft, L., \& Hoey, C. (2001). PR Marketing and the Internet: Implications for information professionals. Library Management, 22(1/2), 68-74. https://doi.org/10.1108/01435120110358952

Awan, A. G., Ismail, M., Majeed, F., \& Ghazal, F. (2015). Effects of advertisement on consumer's buying behavior with references to FMCGs in southern Punjab-Pakistan. Journal of Marketing and Consumer Research, 19, 22-30.

Barry, T. E., \& Howard, D. J. (1990). A review and critique of the hierarchy of effects in advertising. International Journal of advertising, 9(2), 121-135. https://doi.org/10.1080/02650487.1990.11107138

Belch, G. E., \& Belch, M. A. (2003). Advertising and Promotion: An integrated marketing communications perspective (6th ed.). The McGraw Hill Company.

Bludova, T., Chuzhykov, A. V., \& Leshchenko, K. (2019). Modeling the function of advertising reviews from media ads on the YouTube channel.

Bove'e, C. L., \& Arens, W. F. (1992). Contemporary Advertising (4th ed.). Homewood: Richard D. Irwin, Inc.

Bray, J. P. (2008). Consumer behavior theory: Approaches and models.

Brierley, S. (2002). The advertising handbook. Routledge.

Brody, R. P., \& Cunningham, S. M. (1968). Personality variables and the consumer decision process. Journal of Marketing Research, 5(1), 50-57.

Chukwu, B. A., Kanu, E. C., \& Ezeabogu, A. N. (2019). The impact of advertising on consumers buying behaviour. International Journal of Arts and Commerce, 8(1), 1-15.

Elnaga, A. A., \& Abunayyan, S. S. (2016). Determinants and consequences of advertising on consumer trust and buying behavior. Journal of American Science, 12(4).

Fatima, S., \& Lodhi, S. (2015). Impact of advertisement on buying behaviours of the consumers: Study of cosmetic industry in Karachi City. International journal of management sciences and business research.

Field, A. P. (2005). Discovering statistics using SPSS (2nd ed.). London: Sage.

Furaiji, F., Łatuszyńska, M., \& Wawrzyniak, A. (2012). An empirical study of the factors influencing consumer behaviour in the electric appliances market. Contemporary Economics, 6(3), 76-86.

Furaiji, F., Łatuszyńska, M., Wawrzyniak, A., \& Wąsikowska, B. (2016). Study on the influence of advertising attractiveness on the purchase decisions of women and men.

Ghirvu. A.I. (2013). The AIDA model for advergames. The USV Annals of Economics and Public Administration, $13(1), 90-98$.

Glowa, T., (2002). Advertising process models.

Harahap, D. A., \& Amanah, D. (2020). Determinants of consumer purchase decision in SMEs. International Journal of Scientific \& Technology Research, 9(3), 3981-3989.

Hassan, A. (2016). Effects of TV advertisement on consumer buying behavior: A comparative study of rural-urban and male-female consumers. International Journal of Innovation and Applied Studies, 11(3), 608.

Hemamalini, K. S., \& Kurup, S. K. (2014). Effectiveness of television advertisement on purchase intention. International Journal of Innovative Research in Science, Engineering and Technology, 3(2).

Hoang, A. T. (2013). Impact of humor in advertising on consumer purchase decision.

Ingavale, D. R. (2013). Impact of advertisements on purchase decision of youth with reference to consumer goods. Advances in management, 6(9).

Jones, J. P. (2002). The ultimate secretes of advertising. London: Sage Publications

Kabarwala, N. R. (2019). Impact of advertising on consumer buying behavior. International Journal of Advanced Research in Management and Social Sciences, 8(4), 209-223.

Kamins, M. A., Brand, M. J., Hoeke, S. A., \& Moe, J. C. (1989). Two-sided versus one-sided celebrity endorsements: The impact on advertising effectiveness and credibility. Journal of advertising, 18(2), 4-10. https://doi.org/10.1080/00913367.1989.10673146

Khan, N. G. S., Siddiqui, J., Shah, B. A., \& Hunjra, A. I. (2012). Effective advertising and its influence on 
Lau, H. H. J., Wah, N. C., \& Khalique, M.

consumer buying behaviour. Information Management and Business Review, 4(3), 114-119. https://doi.org/10.22610/imbr.v4i3.971

Khaniwale, M. (2015). Consumer buying behaviour. International Journal of Innovation and Scientific Research, 14(2), 278-286.

Lavidge, R. J., \& Steiner, G. A. (1961). A model for predictive measurements of advertising effectiveness. Journal of Marketing, 25(6), 59-62. https://doi.org/10.1177/002224296102500611

Li, W., \& Darban, A. (2012). The impact of online social networks on consumers' purchasing decision: The study of food retailers.

Maheshwari, P., Seth, N. \& Gupta, A.K. (2016). An empirical approach to consumer buying behavior in Indian automobile sector. Industrial and Commercial Training, 48(3), 156-162. https://doi.org/10.1108/ICT-09-2015-0061

Martins, J., Costa, C., Oliveira, T., Gonçalves, R., \& Branco, F. (2019). How smartphone advertising influences consumers' purchase intention. Journal of Business Research, 94, 378-387. https://doi.org/10.1016/j.jbusres.2017.12.047

McGuire, W. J. (1969). An information - processing model of advertising effectiveness. Chicago: Symposium on Behavioral and Management Science in Marketing.

Micheal, S. L. (2004). Unit of Analysis. SAGE Encyclopedia.

Montgomery, D. C., Peck, E. A., \& Vining, G. G., (2012). Introduction to linear regression analysis. NJ: John Wiley \& Sons, Inc.

Mullner, R., Baca, E. E., Holguin, J., \& Stratemeyer, A. W. (2005). Direct-to-consumer advertising and young consumers: building brand value. Journal of Consumer Marketing.

Niazi, G. S. K., Siddiqui, J., Alishah, B., \& Hunjra, A. I. (2012). Effective advertising and its influence on consumer buying behavior. Information management and business review, 4(3), 114-119. https://doi.org/10.22610/imbr.v4i3.971

Noursina, M., \& Ghaffari, N. (2015). An impact of advertisements on purchase decision of youth with reference to consumer goods. Journal of Management and Accounting Studies, 3(1), 27-32.

Palcu, J., Haasova, S., \& Florack, A. (2019). Advertising models in the act of eating: How the depiction of different eating phases affects consumption desire and behavior. Appetite, 139, 59-66. https://doi.org/10.1016/j.appet.2019.04.007

Perreault, W. D., \& McCarthy, J. E. (1997). Essentials of marketing: A global managerial approach (7th ed.). McGraw Hill.

Preston, I. L. (1982). The association model of the advertising communication process. Journal of Advertising, 11(2), 3-15.

Priyanka, S. (2012). A study on impact of online advertising on consumer behavior (with special reference to e-mails). International Journal of Engineering and Management Sciences, 3(4), 461-465.

Ramachander, S. (1988). Consumer behavior and marketing: Towards an Indian approach. Economic and Political Weekly, 23(9), 22-25.

Rameez Bava, A. (2020). Impact of media advertisement on consumer behaviour.

Rehman, F., Hyder, S., \& Ali, S. (2015). A qualitative approach to analyze marketing communication based on AIDA Model. Information Management and Business Review, 7(5), 44-54. https://doi.org/10.22610/imbr.v7i5.1174

Robbs, B. (2009). Advertising, s.1.: Microsoft Student Encarta: Microsoft Corporation.

Roland, R. (1986). Advertising media models. Lexington, M.A: Lexington books

Rossiter, J. R., \& Percy, L. (1985). Advertising communication models: NA advances in consumer research. Association for consumer research, Volume 12, pp. 510-524

Rowley, J. (1998). Promotion and Marketing communications in the information marketplace. Library Review, 47(8), 383-387.

Rudell, F. (1993). Gender differences in consumer decision making for personal computers: A test of hypotheses. Association of Consumer Research.

Sah, S. K. (202 0). Impact of advertising on consumer purchase decision (Doctoral dissertation).

10 Consortia Academia Publishing (A Partner of Tourism Educators and Movers of the Philippines) 
Sama, R. (2019). Impact of media advertisements on consumer behavior. Journal of Creative Communications, 14(1), 54-68.

Senecal, S., \& Nantel, J. (2004). The influence of online product recommendations on consumers' online choices. Journal of retailing, 80(2), 159-169. https://doi.org/10.1016/j.jretai.2004.04.001

Singh, B. (2012). Impact of advertisement on the brand preference of aerated drinks. Asia Pacific Journal of Marketing \& Management Review, 2(2), 147-160.

Smit, E. G., Van Meurs, L., \& Neijens, P. C. (2006). Effects of advertising likeability: A 10-year perspective. Journal of Advertising Research, 46(1), 73-83. https://doi.org/10.2501/S0021849906060089

Solomon, M. (1995). Consumer behaviour. Prentice Hal, New Jersey.

Teixeira, T., Picard, R., \& El Kaliouby, R. (2014). Why, when, and how much to entertain consumers in advertisements? A web-based facial tracking field study. Marketing Science, 33(6), 809-827.

Varghese, B. A., \& Chitra, D. S. (2020). The role of online advertisement on customer attitude-A Study. Palarch's Journal of Archaeology of Egypt/Egyptology, 17(6), 2788-2794.

Warmke, R. F., Wyllie, E. D., \& Sellers, B. E. (1977). Consumer decision taking: Guide to better living. 2nd ed.

Williams, C. (2007). Research methods. Journal of Business and Economic Research, 5(3). https://doi.org/10.19030/jber.v5i3.2532

Yelbert, M. N. A. (2010). Effects of advertising of hair products on student's purchasing habits. Accra.

York, E. B. (2008). Brand vs. brand: Attack ads on the rise. Advertising Age, 79(40), 1-28.

Zeng, M., Cao, H., Chen, M., \& Li, Y. (2019). User behavior modeling, recommendations, and purchase prediction during shopping festivals. Electronic Markets, 29(2), 263-274.

https://doi.org/10.1007/s12525-018-0311-8 
Lau, H. H. J., Wah, N. C., \& Khalique, M.

12 Consortia Academia Publishing (A Partner of Tourism Educators and Movers of the Philippines) 